\title{
La de-construcción de una identidad masculina tóxica en El Rey de La Habana de Pedro Juan Gutiérrez'1
}

\author{
Massimiliano Carta ${ }^{2}$
}

\footnotetext{
1 Financiación o proveniencia del artículo: La presente investigación es producto de la estância de investigación posdoctoral en el Grupo de Investigación GECA de la Facultad de Ciencias de la Información de la Universidad Complutense de Madrid y ha sido elaborada durante la estancia doctoral en la facultad de Artes y Letras de La Habana (Cuba) promovida por la Beca Marco Polo de la Universidad de Bolonia.

${ }^{2}$ Realiza sus estudios en la Universidad de Sassari donde obtiene el título de Licenciado en Español y Literaturas Hispanoamericanas con una tesis sobre: "Machismo y homosexualidad en Antes que anochezca de Reinaldo Arenas". El mismo año se traslada a Parma donde cursa algunas asignaturas del Master en Ciencias y Técnicas del Espectáculo del Departamento de Bienes culturales y del espectáculo. Doctor en Literaturas Clásicas, Modernas, Comparadas y Postcoloniales de la Universidad de Bolonia con especial énfasis en Literaturas y culturas Hispanoamericanas. Sus principales intereses investigativos son los Estudios de Género, los Queer Studies y los Estudios Visuales. Ha publicado en blogs, revistas independientes y académicas. Ha participado en varios congresos y charlas a nivel local, nacional e internacional. Ha realizado estancias de investigación en Cuba, Colombia, Espaòa y Ecuador. Es miembro del Grupo de Investigacion Feliza Bursztyn de la Facultad de Artes de la Universidad del Atlantico de Barranquilla (Colombia). Actualmente es profesor catedratico en el Instituto de Idiomas de la Universidad del Norte de Barranquilla.

Email: massimilianocartastudio@gmail.com
} 


\section{Resumen}

Esta propuesta se plantea un acercamiento a la transposición cinematográfica dirigida por Agustí Villaronga de la novela El Rey de la Habana del cubano Pedro Juan Gutiérrez. Desde una perspectiva de género se analiza la formación de una identidad masculina en la adolescencia, las relaciones entre los diferentes tipos de masculinidades (nuevas y hegemónicas) en el contexto de una metrópolis latinoamericana y en el ámbito de instituciones formales e informales como la familia, la cárcel, la escuela y la calle que contribuyen a conformarla. Por medio del personaje de Reynaldo analizaremos las dinámicas y las etapas que caracterizan el proceso inagotable de construcción de la masculinidad filtrada por la mirada queer del director y en el confronto con los modelos mediáticos populares y el cine de Pier Paolo Pasolini y Héctor Babenco, promoveremos una reflexión sobre los usos y los lenguajes de la corporeidad.

Palabras clave: masculinidades; cine y literatura; mirada queer, sexualidades metropolitanas.

\section{Resumo}

Esta pesquisa propõe uma abordagem da transposição cinematográfica dirigida por Agustí Villaronga do romance El Rey de La Havana, do cubano Pedro Juan Gutiérrez, a partir de uma perspectiva de gênero que analisa a formação de uma identidade masculina na adolescência e as relações entre os diferentes tipos de masculinidades (novas e hegemônicas), no contexto de uma metrópole latino-americana e no âmbito das instituições formais e informais como a família, a prisão, a escola e a rua, que contribuem para configurá-la. Através da personagem de Reynaldo, analisaremos as dinâmicas e etapas que caracterizam o inesgotável processo de construção da masculinidade filtrado pelo olhar queer do realizador e, no confronto com os modelos populares de mídia e o cinema de Pier Paolo Pasolini e Héctor Babenco, iremos promover uma reflexão sobre os usos e as linguagens da corporeidade.

Palavras-chave: masculinidades; cinema e literatura; olhar queer, sexualidades metropolitanas.

\section{Abstract}

This proposal is an approach to the cinematographic transposition directed by Agustí Villaronga of the novel El Rey de la Habana, by the cuban writer Pedro Juan Gutiérrez, from a gender perspective that analyses the formation of a male identity in adolescence, the relationships between the different types of masculinities (new and hegemonic) in the context of a Latin American metropolis and in the sphere of formal and informal institutions that contribute to its shaping. Through the character of Reynaldo, I analyze the dynamics and stages that characterize the inexhaustible process of construction of a masculinity filtered by the queer gaze of the director and, in the confrontation with popular media models and the cinema of Pier Paolo Pasolini and Héctor Babenco, I promote a reflection on the uses and languages of corporeity.

Keywords: masculinities; cinema and literature; Queer; metropolitan sexualities. 
La cárcel de la dominación masculina: a favor de la paridad entre géneros

La novela El rey de la Habana fue publicada por Pedro Juan Gutiérrez en 1999, justo un año después de la más famosa Trilogía sucia de la Habana. Ambas novelas nacieron de un período muy difícil por el autor a nivel personal, y durante el llamado "período especial".

Con El Rey de la Habana el autor cubano nos ofrece un punto de vista privilegiado en el proceso de formación de un chico que nunca llegará a ser adulto. En esta obra, el elemento evidentemente autobiográfico que caracterizaba la Trilogía se va atenuando; el protagonista ya no se llama como el autor sino Reynaldo, el "Rey de la Habana" del título, debido a sus características anatómicas/sexuales y por su capacidad de sobrevivir a las situaciones más críticas de la vida.

La idea de este libro le vino al autor después que visitó un correccional de menores en Guanabacoa, de cuya experiencia salió un reportaje y la historia de Rey que ha sido llevada a la pantalla grande por Agustí Villaronga y que será objeto de análisis en este artículo.

La historia tratada en la novela - y en la película - es la de un adolescente que ha sido testigo de la muerte de toda su familia, de la cual se le acusa injustamente de ser el responsable. A partir de este choque, de este trauma, la construcción de la identidad masculina del joven sufre un tremendo cambio. Él pasa por todos los procesos indicados por Elisabeth Badinter en su ensayo XY, la identidad masculina (1992): se trata del conjunto de experiencias que permiten a un ser de género masculino superar el período crítico de la infancia indiferenciada para llegar a la plena madurez de hombre adulto. Esas etapas implican pasar por unas pruebas, unos ritos de paso que, a veces, conllevan dolor físico o psíquico. Por medio de algunas figuras de referencia, el niño transforma su identidad primaria femenina en identidad masculina secundaria. Las tres etapas de los ritos de iniciación, presentes en algunas sociedades estudiadas por Badinter (1992: p. 124-134) son:

1. La separación de la madre y del mundo femenino

2. La transferencia a un mundo desconocido

3. El sometimiento a pruebas dramáticas y públicas (escarificación, circuncisión, incisión del pene)

En el caso del personaje creado por Gutiérrez la separación a la cual se refiere el primer punto es aún más difícil, debido a que sucede de manera violenta por manos del único referente masculino del niño, su hermano mayor, que provoca accidentalmente la muerte de la madre y el infarto de la abuela, y que termina suicidándose. 
De repente Rey se encuentra totalmente alejado del universo femenino, familiar y sentimental, que incluye a la vecina por la cual probaba atracción sexual (y que en la película de Villaronga es Magda, la coprotagonista), para terminar en un correccional para muchachos difíciles. Ahí el muchacho encuentra un universo totalmente masculino donde pasa toda su adolescencia y que representa "la transferencia a aquel mundo desconocido" que hemos mencionado antes.

Apenas llega a la institución, el cuerpo de Rey sufre un proceso de higienización y de homologación. Se le corta el pelo, se le priva de su ropa a cambio de un uniforme, se le echa un medicamento contra los parásitos y se le manda directo a la ducha. Es justo ahí, en los baños, que fue sometido a la primera prueba dramática y pública. Un muchacho lo provoca frente a todo el mundo proponiéndole sexo, "tratándolo de maricón" parafraseando el diálogo entre los dos en la película y en la novela. El novato se siente desprestigiado en su virilidad de supuesto "macho" y responde con violencia:

Le tenía odio. Creyó que era maricón y que le podía coger las nalgas y desprestigiarlo delante de todos. Nada de eso. Él era un tipo durísimo. No se le olvidaba el calabozo por culpa de aquel negro bugarrón, pero iba a salir de allí sin más problemas". (GUTIÉRREZ, 1999: p. 19)

Se forma una pelea entre los dos muchachos y Reynaldo termina en el despacho del director del penitenciario. El diálogo con el funcionario es útil para hablar de los dos elementos que según la socióloga australiana Raewyn Connell (1995) tienen un papel fundamental en la construcción de la masculinidad y de las formas de poder relacionadas con ella: la pertenencia étnica y el estatus social:

- ¿QQué es lo que pasó?

- $\quad$ Ese negro me quería coger el culo.

- $\quad$ Exprésese correctamente. Aquí nadie es negro ni blanco ni mulato. Todos son internos.

- $\quad$ Bueno..., lo mismo..., cambie negro por interno.

- ¿ ¿Usted se cree simpático? [...] Conteste.

- Le voy a advertir una cosa: yo soy el instructor suyo.

Yo soy el que decide el tiempo que usted va a estar aquí.

Usted tiene trece años. Si sigue fajándose y provocando desórdenes, va a llegar a los 18 aquí adentro y automáticamente pasa a la cárcel. Automáticamente lo envían a los caimanes para que se lo coman. [...]

Y poniéndose de pie. Con aire marcial: 
- $\quad$ ¡Retírese! ¡Incorpórese a su grupo! (GUTIÉRREZ, 1999: p.19)

En esos contextos la masculinidad y el sexo se convierten en un arma de ataque contra los demás, los más débiles. El carácter autoritario de la masculinidad hegemónica no tiene aquí barreras y puede expresarse en toda su carga violenta. Las relaciones entre presos o internos siguen los tres modelos principales de relación entre los varones, teorizados por Connell (1997: p. 42):

-Subordinación: se produce en situaciones específicas en el marco del modelo hegemónico; un ejemplo pueden ser las relaciones de poder entre heterosexualidad $y$ homosexualidad en las cuales esta última ocupa la posición del abyecto.

-Complicidad: Es el apoyo y el hecho de compartir los privilegios utilizados contra una u otra minoría.

-Marginación: se produce cuando el orden de género se intersecta con otras estructuras como la etnia y la clase social.

Estas relaciones conforman la "pirámide de poder masculino" que ve en su ápice al hombre blanco, adulto, heterosexual, occidental, rico, pero, sobre todo, fuerte, viril, etc.... Ese supuesto ideal de masculinidad alimentado por la mayoría de las sociedades por medio de las instituciones de socialización como la familia, la escuela, los grupos de pares y los medios de comunicación, de acuerdo con María Ángela López (1995), alimenta la construcción social del "devenir varón" como parte de un proceso psicosocial que la estudiosa citada por Patricia Ruiz Bravo (2001), llama "sociogénesis del varón".

Rey parece haber asimilado esa jerarquía y su contenido racista cuando afirma, en un diálogo con Magda: "yo no soy negro, no confundas" (GUTIÉRREZ, 1999: p. 59), colocándose así en una posición superior comparado a otros hombres. La masculinidad hegemónica, nos demuestra Ruiz Bravo, citando las teorías de Michael Kimmel:

Hace que las otras masculinidades sean vistas como no prestigiosas y por lo tanto sean subsumidas y subordinadas al patrón predominante. Este tipo de masculinidad, detentada por los grupos de poder, pasa por natural y universal y no como imposición. El mismo sistema de poder incluye otras diferenciaciones sociales como la clase, la etnia... (RUIZ BRAVO, 2002: p. 45)

Estos estudios confirman el carácter variable de la posición hegemónica, así como expresado por Connell (1995), cuyos factores variables hacen que la posición de 
dominio sea siempre disputable y que, por lo tanto, necesite que la masculinidad sea permanentemente probada y reforzada. En este sentido, el pensamiento de la socióloga australiana nos recuerda a Bourdieu cuando afirma que: I'illusio masculina es el motor de los juegos sociales que hacen que el sujeto masculino se perciba como hombre de verdad (por su sentido del honor, virilidad, manliness o cabilidad) y en regla consigo mismo, para seguir siendo digno, ante sus propios ojos (BOURDIEU, 1998: p. 37).

La última prueba a la cual se somete Rey antes de escapar del correccional y enfrentar la vida de la calle es la aplicación de unas perlas de acero en el pene (o mejor dicho "perlanas", según la jerga presidiaria), gracias a las cuales se convertirá dentro de poco en el Rey de la Habana:

Después de abandonar su plan de fuga se interesó por las perlanas en el glande. En la enfermería siempre había alguien con la herida infectada. Esos tenían mala suerte: les curaban la infección y además les operaban y les extraían la perla. Pero a otros muchos les salía bien y nadie se enteraba. Algunos se colocaban hasta tres perlanas. Eran municiones de acero, de los rodamientos de bicicletas. Dos tipos se dedicaban a eso. [...] Le hicieron cuentos de cómo las mujeres se vuelven locas con esas perlanas en el glande, "perlanas" en el argot de presidio. [...] Le pusieron las dos municiones de acero, aunque insistían en llamarlas "perlas". No soltó mucha sangre. Se tragó un buche de alcohol para resistir mejor el dolor. Cuatro días después ya estaba sana la herida. Cuando saliera para la calle podría decir a las jevas que era marinero y que las perlanas se las colocaron en China. Eso decían todos los presidiarios con perlas en el glande. Nadie decía que estaba guardado en el tanque. Nadie decía la verdad. En este mundo todo es mentira. (GUTIÉRREZ, 1999: p. 22)

Este acto corporal auto infligido contribuye a la construcción de la masculinidad de Rey. Con esta prótesis el muchachito se siente más "hombre" porque lo ve como un fortalecimiento de su propia virilidad. Rey es el tipo de hombre del cual habla Badinter:

El que no solo toma conciencia de su identidad y de su virilidad a través del sexo y de la actividad intelectual, como suele pasar, sino que: "obsesionado por su virilidad, ya no considera al sexo como un órgano de placer, sino como una 
herramienta, un instrumento para realizarse, como algo separado de él. (BADINTER, 1992: p. 227)

Rey se siente "hombre de verdad": él que no llora, él que no sufre, él que es invencible. El que en realidad no quiere darse cuenta que ese mito del "superhéroe" es parte de la mentira de este mundo.

Decía Norman Mailer (1971) que "Ser hombre, es la batalla inconclusa de toda una vida”. Según Badinter (1992: p. 214): "El hombre se pasa la vida luchando contra sí mismo para no ceder ante la debilidad y la pasividad que lo acechan". Es un combate sin victoria que si es llevado a los extremos, conduce a la muerte.

Este ideal masculino que Badinter define del "hombre Marlboro" se basa en 4 imperativos enunciados por Deborah S. David y Robert Brannon (1976):

1. Nada afeminado (no sissy stuff). [Abandono de la parte femenina].

2. Ser un "pez gordo" (to be the big Wheel). [Exigencia de superioridad].

3. Ser independiente y valerse por sí mismo (The sturdy oak)

4. Ser más fuerte que los demás (Give'em hell)

Para Rey conseguir estos objetivos será una lucha sin fin que perderá bajo varios frentes, así como nunca llegará a encajar completamente en la última de las tres configuraciones que según Norma Fuller (1997: p. 173) contienen las representaciones de la masculinidad:

1. La dimensión natural (sexualidad activa, fuerza física, virilidad)

2. La exterior (calle, aspectos salvajes, competencia, rivalidad, seducción basado en la jerarquía)

3. La doméstica (paternidad y casa, responsabilidad, protección, respeto).

En la obra literaria de Pedro Juan Gutiérrez, Reynaldo se relaciona con muchísimas mujeres y pasa por varias vicisitudes sexuales, a menudo muy complejas. En la adaptación para el cine de Villaronga serán parcialmente omitidas y las características y las acciones de los varios personajes femeninos serán reunidas en las dos figuras más relevantes de la película: Magda, interpretada por Yordanka Ariosa y Yunisleidi (Sandra) interpretada por Héctor Medina. La primera es una prostituta afrodescendiente, practicante de la Regla de Ocha-Ifa, de la cual Rey termina enamorándose, la segunda es una chica transgénero que se prostituye en un local con extranjeros y que sueña con tener una familia. En el libro, si bien ambas tienen un papel 
importante, ninguna de la dos destaca particularmente de las otras figuras femeninas. Especialmente Yunisleidi.

Estas mujeres juegan un papel ambiguo respecto a Rey: si por un lado ponen en duda de manera contundente su "realeza", y lo humillan, como en el caso de Magda, por otro lado, lo desean, lo disfrutan y terminan cuidándolo y probando un sentimiento genuino hacia él:

Yo me llamo Sandra. Apréndetelo. San-dra. San-dra. No me digas "oye". No me gustan las vulgaridades. [...] Yo soy así, como una princesa.

- $\quad$ Ah, pues a mí me dicen "El Rey de la Habana"

- $\quad$ Eso tienes que demostrarlo. Ese es un título nobiliario de alcurnia..., tienes que demostrarlo.

Eso mismo dice Magda (GUTIÉRREZ, 1999: p. 64)

En la película, así como en la novela, Yunisleidi y Magda son descritas como dos reinas de La Habana que compiten para su marido:

- $\quad$ Yo tengo un hijo de cinco años..., con un negro

- ¿ ¿Y dónde está?

- En el campo, con una de mis hermanas

- ¿Y eso?

- $\quad$ Ellos dicen que estoy loca y que el niño se iba a morir de hambre.

- ¿Y estás loca de verdad?

- $\quad$ Si, de la cintura pa' abajo. Loca por meterme todas las pingas que me gustan. Si tú eres el rey de La Habana, yo soy la Reina papito, La Reina de La Habana. (GUTIÉRREZ, 1999: p. 69)

Mientras Sandra frente a su amiga y colega Yamile que acusa Rey de explotarla afirma: Yamile lo miró (a Rey), hasta que no pudo soportar más y explotó:

- $\quad$ Oye, Sandra, ¿cuál es la explotación de este tipo contigo? ¿Que repinga te pasa con este churrosomuertodehambre?

Ay, Yamile, déjame. Él es el Rey de La Habana y es mi marido, así que soy La Reina de La Habana, jajajaj... El Rey y su Reina... (GUTIÉRREZ, 1999: p. 97)

Si por un lado las dos chicas se presentan como contrarias a los dictámenes de la sociedad heteropatriarcal, es decir como "independientes, libres y soberanas", en 
realidad terminan confirmándolos: Sandra esperando que aparezca en su vida "un millonario, como en las novelitas. "Un tipo canoso, alto, elegante, con un castillo en Europa" (GUTIÉRREZ, 1999: p. 77), que se enamore de ella y que le "deje parirle y ser madre, ama de casa y con alguien que la represente". Mientras que Magda termina definiendo al padre de su hijo en estos términos:

¡Estuve con el padre de mi hijo! Ese sí es un hombre.

Que me atiende, me da ropa, comida, dinero, me saca a pasear. Ese Negrón sí es un hombre [...] ¡Tú eres un muertodehambre! ¡Un inútil! ¡Un cagao! Esperando aquí por mí, maricón. A mí me gustan los hombres no los niños como tú [...] si estoy preña es de él. Pa' que lo sepas y no te hagas el bárbaro. ¡Le voy a parir otro hijo más! (GUTIÉRREZ, 1999: p. 212)

Sandra y Magda parecen adherirse perfectamente a los dictámenes de la masculinidad hegemónica que "legitima el patriarcado y garantiza la posición dominante de los hombres" (RUIZ BRAVO, 2002). Esta jerarquía de poder basada en un orden de género les queda invisible, así como lo es para los varones que gozan de sus privilegios. (KIMMEL, 1998)

Bourdieu (1998: p. 47) afirma que "En esta manera las clasificaciones se vuelven jerarquías y la imposición se materializa a través de la equiparación entre orden social y masculinidad hegemónica".

Rey, a diferencia de lo que pensaba cuando creía esperar un hijo de Magda, no parece haber alcanzado la etapa más avanzada de su "devenir hombre" que según Norma Fuller (1997), significa pasar de la virilidad (lado natural) a la hombría (producto cultural) cuyo objetivo es ser buen padre y adulto.

El protagonista de la novela de Gutiérrez está destinado a quedarse "niño" a los ojos de las mujeres que siguen cuidándolo como a un hijo: le dan comida, lo visten, lo lavan y le dan dinero. Él, así como ellas, perpetúan la violencia simbólica: es decir la que se ejerce sobre un agente social con su complicidad, el cual la toma como natural y no como una imposición. La dominación masculina es paradigmática de la violencia simbólica, la misma que no permite a Rey admitir sus deseos homoeróticos.

La reacción de Rey al rechazo de Magda que quiere dejarlo es muy violenta, entre otras razones porque alude a estos innombrables deseos y a sus debilidades. La imagen ideal, que el muchacho había construido de sí mismo se derrumba de repente y revela todas sus inseguridades y fragilidades. La fachada, que en el sentido de Erving Goffman (1970) es la necesidad de exhibir frente a los demás las propias conquistas, se cae. El chico-macho, no puede permitir que estas emociones sean reveladas "a su 
posesión a distancia" (Norman Palma, 1990) y ni siquiera sabe cómo manejarlas, así que termina matando a Magda.

La hipervirilidad ha sido para Rey el remedio contra un constante sentimiento de inseguridad. $Y$ esa misma lo hizo prisionero de una masculinidad enferma que lo lleva a la autodestrucción y alimenta su agresividad contra quien amenaza con hacerle caer la máscara. Según Elisabeth Badinter (1992: p. 220) "La promoción de la imagen inaccesible de virilidad genera una dolorosa toma de conciencia: la de ser un hombre incompleto".

La muerte de Magda, así como la explotación y la ceguera de las cuales fue víctima Sandra - debida a la extracción de sus globos oculares para vender la retina tienen causas comunes: se deben a esa construcción social que atribuye, según López (1995), el éxito del sujeto a la capacidad de ejercer la violencia y que se basa en jerarquías y poderes y no en complementariedades e igualdad de derechos.

La homofobia, la transfobia y la misoginia se colocan en el mismo marco; así como afirma Badinter:

Constituyen las dos caras de la misma moneda: homofobia es odio a las cualidades femeninas en el hombre y misoginia a las cualidades femeninas en la mujer. La masculinidad tradicional se define por el hecho de evitar algo. Ser hombre significa no ser femenino, no ser homosexual, no ser dócil, dependiente o sumiso, no ser afeminado, no tener relaciones sexuales con hombres, no ser impotente con las mujeres.

(BADINTER, 1992: p. 192)

Badinter resume las posiciones de Erik Erikson (1983), John Money (1972) y de Ruth E. Hartley (1959), admitiendo que "la adquisición de la identidad implica y se basa en la inclusión y la exclusión (semejanzas y diferencias) es decir de diferenciación" y que "el niño se define ante todo por vía negativa: es masculino todo lo que no es femenino" (BADINTER, 1992: p. 60-61). Esto no autoriza que se llegue a los extremos hacia los cuales el modelo heteropatriarcal puede conducir si no se activan los necesarios anticuerpos que permitan una convivencia enriquecedora, solidaria y justa entre todos los seres humanos.

Una propuesta eficaz en este sentido viene de Norma Fuller (1997: 175) que identifica unos discursos contra hegemónicos en el discurso femenino, homosexual y marginal que se oponen a que la masculinidad dominante sea la ley y la verdad única posible. Eso puede pasar a través de prácticas de subversión del género (en referencia al poder o a los roles y las estéticas) o por medio de una literatura que pueda configurar cambios en el imaginario social. 
Del papel a la película: el voyeurismo del cine y la mirada deseante queer

La transposición cinematográfica de Agustí Villaronga nos confirma sólo en parte el punto de vista sobre la masculinidad de la novela de Pedro Juan Gutiérrez. Si por un lado intenta reproducir el vagabundaje erótico y existencial del protagonista literario, por el otro cambia totalmente el punto de vista. De cuerpo deseante e insaciable, el de Rey se vuelve un objeto de deseo, no solo de los personajes femeninos sino del mismo director. Como prueba de esta tesis se pueden aducir las numerosas escenas de desnudez que intentan evidenciar los volúmenes, la proporción de las formas anatómicas y la carga sexual de un cuerpo erotizado por una mirada ajena. Los primeros planos, las poses esculturales, el acento puesto en los líquidos corporales, como el sudor, que vienen de la danza o de los coitos parecen construir este tipo de narración y confirmar un proceso de cosificación (Figuras 1-2).

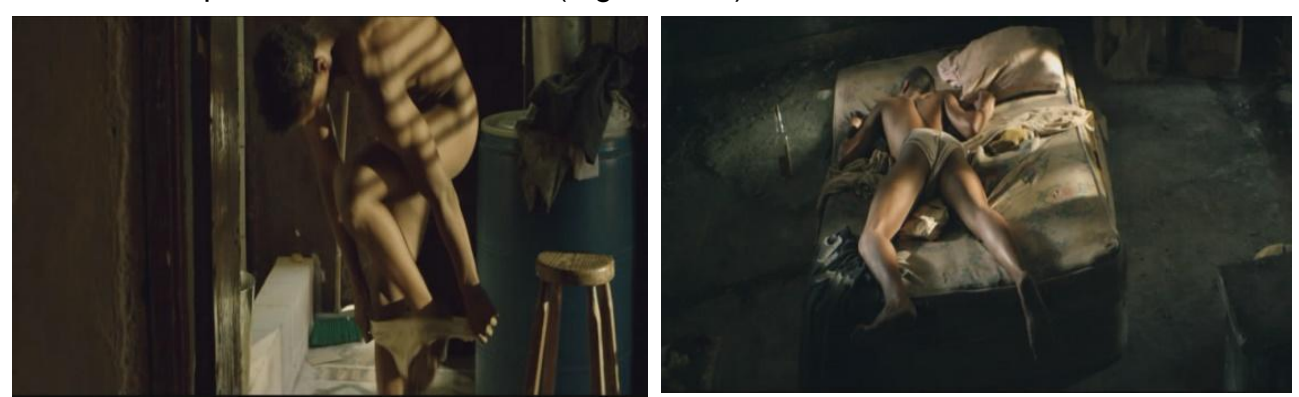

Figuras 1 y 2: Fotogramas extraídos de El Rey de la Habana. Maikol David, protagonista de la película, en algunas escenas eróticas. Fuente: DVD Filmax Home Video.

Lo mismo pasa con los otros personajes masculinos que se enfrentan 0 acompañan a Rey en su proceso de crecimiento personal, y que en la película vienen presentados en actitudes que enfatizan sus características físicas masculinas. Casi todos los muchachos que aparecen en actitudes sexuales pertenecen al mismo fenotipo humano, como si estuviéramos frente a un proceso de fetichización.
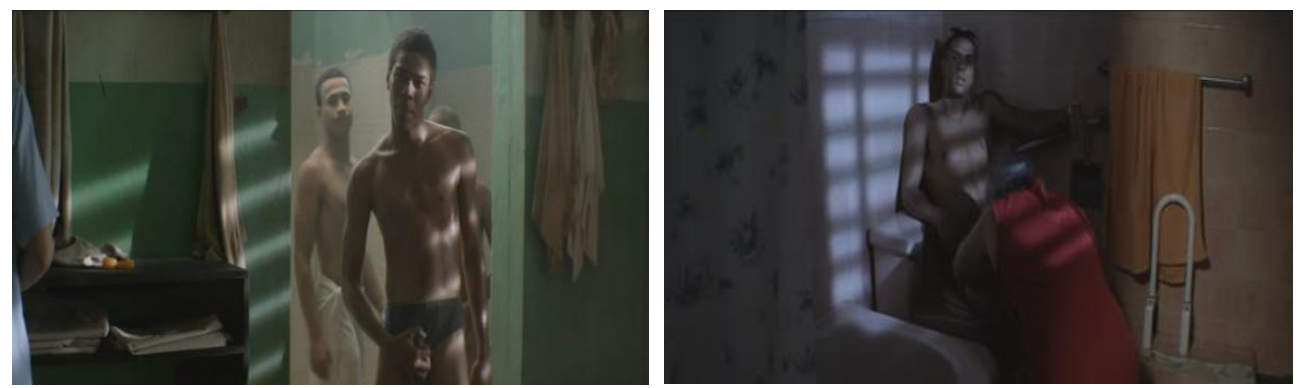

Figuras 3 y 4: Fotogramas extraídos de El Rey de la Habana. De izquierda a derecha la escena de las duchas en el correccional y una escena de prostitución de Cheo. Fuente: DVD Filmax Home Video. 
Al mismo tiempo, todavía, se trata de escenas que de alguna forma generalizan la visión falocéntrica de Rey que reduce toda la construcción de su propia identidad masculina al ámbito genital, valorando así un código verbal y gestual que vehicula un subtexto machista. Gómez Rivera (2018: p. 98) analiza las expresiones recurrentes y alusivas de virilidad en el mundo del deporte y pone en evidencia un lenguaje que hace referencia constante a las zonas erógenas masculinas como "zonas de poder" de forma parecida a la que se encuentra en El Rey de La Habana:

La carencia o el mucho huevo es una medida para saber el grado de masculinidad de cada persona. La centralidad de los testículos masculinos es determinante para sopesar la valentía, en relación al tamaño: a mayorhuevos, mayor masculinidad. Asimismo, el término «poner huevos» indica: poner garra, pasión, amor en el campo del fútbol, actitudes necesarias para lograr el triunfo. Es una manera de expresar superioridad ante el rival, es una forma de demostrar valentía, coraje. Con esta centralidad simbólica de los huevos como representación de una serie de atributos de virilidad, también se representa el poder que se establece con el otro, una relación de superioridad y dominación, donde el que tiene más huevos subordina al resto, lo que se resume en la idea que los derrotados como muestra de su sumisión besen los testículos al ganador. En virtud de esto, los sujetos deben demostrar que tienen huevos a través de distintas prácticas como la lucha corporal contra sus adversarios, en el partido $y$ en otras formas donde demuestre su aguante, como afirmación de su masculinidad. No solo se debe hablar de que se tiene huevos, también es necesario medirlos a través del enfrentamiento real. (MARTÍNEZ GUIRAO, 2019: p. 97)

El enfrentamiento a través de la lucha es exactamente la manera en que las escenas a las cuales pertenecen las figuras 3 y 4 se concluyen: la primera se refiere al fragmento en el cual un Rey adolescente se enfrenta a un chico en las duchas para ganarse el reconocimiento del grupo de pares. En la segunda, el hermano de la amante de Rey se pelea con un cliente que no quiere pagar la prestación sexual de la chica, y termina matándolo. Ambos comportamientos confirman la teoría de Eric Pescador (2004: p. 198) sobre la masculinidad tóxica como factor de riesgo que puede llegar a producir actos criminales con el solo fin de confirmar (a sí mismo y a los demás) el dominio de 
las supuestas cualidades masculinas como la fuerza, la resistencia, la superioridad, la autoridad y el coraje, que se piensa tengan que caracterizar al supuesto "macho alfa" en ámbito público y privado a través del culto del cuerpo como ejercicio de poder, del sexo, del trabajo manual y hasta del deporte. Encontraremos confirmación a esta teoría también en las obras de Pier Paolo Pasolini y Hector Babenco, Accattone y Pixote, cuyos personajes responden a llamados parecidos a los de Villaronga y Gutiérrez.

En el intento de salvaguardar su reputación como "hombre - varón - masculino" (GONZÁLEZ PAGÉS, 2010) dentro de una "cultura de la honra" (GONZÁLEZ PAGÉS, 2019: p. 74) estos sujetos se alimentan de la convicción de tener que "defender" a "sus" mujeres y a la familia de supuestos peligros y que, en realidad oculta, muchas veces, un deseo de control/posesión y una objetivación del sujeto femenino (FACHEL, 1997). Norman Palma (1990) afirma al respecto que un elemento clave del machismo es el principio de territorialidad que se expresa en:

1. Una relación de posesión inmediata (hacerla suya)

2. Una relación de posesión a distancia (cuando la mujer está embarazada y "ocupada" por el varón)

En el caso de situaciones límites de marginalidad o de alto riesgo, como pueden ser las pandillas o las zonas fronterizas (o las de Rey, Accattone o Pixote) el machismo se vuelve un mecanismo de defensa para no sucumbir ante los sujetos considerados más peligrosos (GONZÁLEZ PAGÉS, 2019). Todos estos aspectos caracterizan las dinámicas entre Rey y Magda que llevaron al homicidio de la muchacha por mano del hombre que se declaraba enamorado de ella.

Villaronga propone el mismo conmixtión entre pasión amorosa y muerte sugerida por Pedro Juan Gutiérrez en la novela, reconstruyendo además la escena cruel de necrofilia que concluye la obra literaria e intentando buscar en las imágenes algo poético a partir de los cuerpos desnudos cubiertos de basura (figuras 5-6). Liricidad que no consigue ocultar el drama frente a la exposición del enésimo "crimen pasional" que sería más apropiado definir feminicidio.
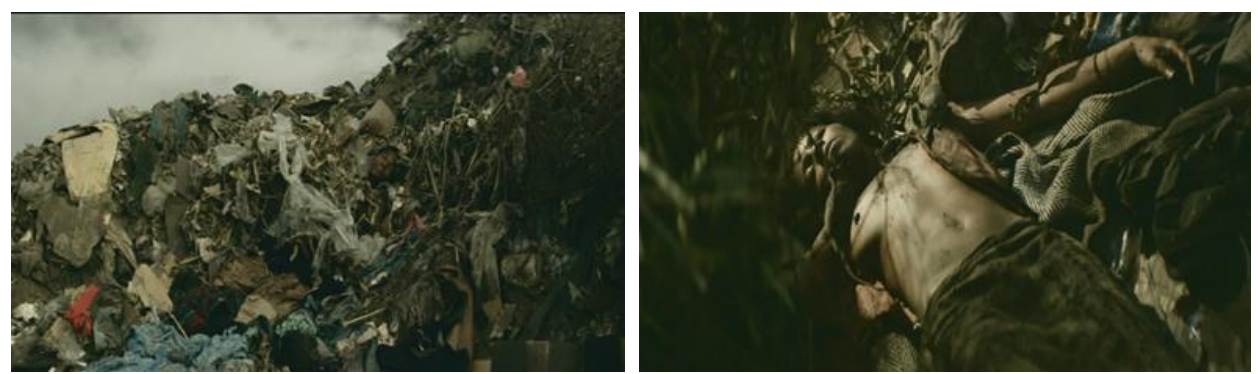

Figuras 5 y 6: Fotogramas extraídos de El Rey de la Habana. De izquierda a derecha la muerte de Rey en el basurero y el cuerpo abandonado de Magda después del homicidio. Fuente: DVD Filmax Home Video. 
El final trágico confirma cierta áurea maldita que caracteriza las obras de Pedro Juan Gutiérrez y que el producto fílmico quiere conservar para el público internacional occidental mediante un lenguaje visual que le resulte familiar: recurriendo al estereotipo sexual de los hombres afrodescendientes o a íconos populares del rock blanco. Tal propósito ya es evidente a partir de uno de los carteles de la película que representa a la capital cubana incluida en la pantaloneta del protagonista y que apenas disimula un primer plano de la ingle del muchacho (Figura 7). La imagen parece querer evocar la legendaria cubierta del disco de los Rolling Stones, Stickly Fingers, ideado por Andy Warhol.

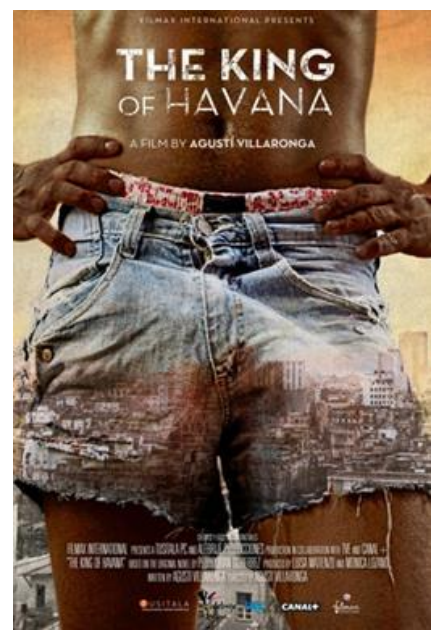

Figura 7: Afiche de El Rey de la Habana (The King of Havana) para el mercado internacional. Fuente: Printerest.es.
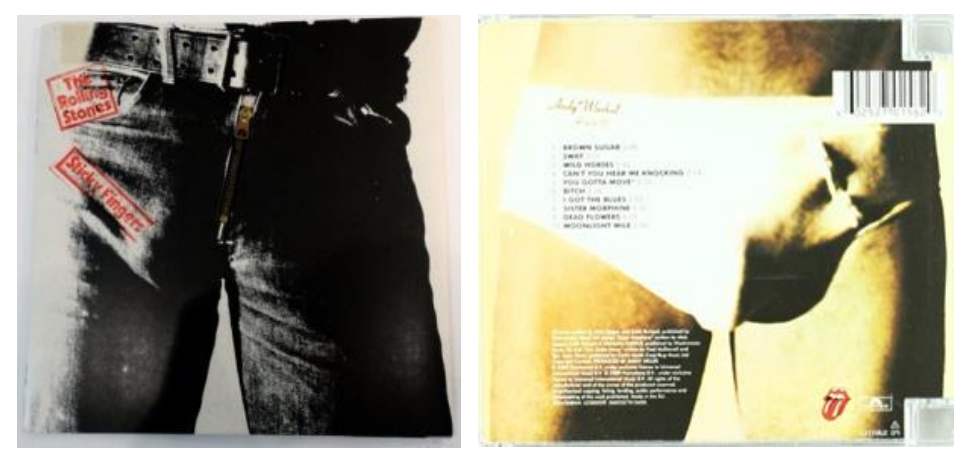

Figuras 8 y 9: Portada y contraportada de Sticky Fingers de los Rolling (1971). Fuente: Amazon.com.

Las primeras copias del packaging del disco incluían una cremallera de verdad, bajando la cual se podía ver lo que cubría: la pelvis de un hombre cubierta por unos pequeños calzoncillos blancos, a sugerir un desvelamiento y una exaltación del potencial 
erótico del sujeto del retrato (Figuras 8-9). El mismo concepto ya se había experimentado para el legendario álbum de los Velvet Underground (Fig.10) por el mismo artista neoyorquino, un par de años atrás y que contenía la provocativa invitación a "Pelarla despacio y mirar" (Peel slowly and see).
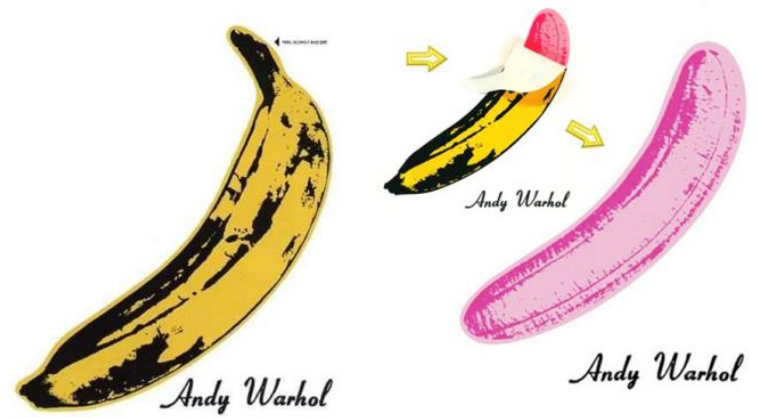

Figura 10: Portada del primer disco de los Velvet Underground \& Nico creada e ilustrada por Andy Warhol en 1967.

El banano con su forma llamativa al falo se convirtió en objeto de deseo y fetiche sexual pero al mismo tiempo en una sublime forma de arte pop. Más allá de exaltar una masculinidad hegemónica, un análisis detallado del behind the scenes de estos productos visuales, nos revela un carácter ficticio detrás de la hipérbole de la mirada deseante de lo masculino y hacia él. A comenzar por el hecho de que las partes íntimas retratadas en el disco de los Stones no pertenecen todas a la misma persona (el hombre de los vaqueros no es el mismo de los calzoncillos). Así como la imagen del plátano es evidentemente artificial por sus colores, sus formas y el estilo que denuncia su origen publicitario.

Lo mismo pasa cuando descubrimos que el pene gigante que varios actores muestran en la película de Villaronga en realidad es una prótesis producida por una agencia de efectos especiales: la May effects de Pablo Perona ${ }^{3}$

Andy Warhol, así como el director español, juegan con sus propios fantasmas, y con los del público, proponiendo una supuesta hipervirilidad que es todo un engaño sobre el cual se puede (y se debería) ironizar para poder desactivar por medio de la risa los mecanismos nocivos que llevarían el pensamiento de superioridad o supremacía con base anatómica del machismo a concretizarse. Es lo mismo que intenta hacer Pedro Juan Gutiérrez cuando afirma que "lo que le parece hacer en sus libros es burlarse del machito tropical" (MENCHÉN, 2002: s.p.)

Las primeras imágenes de El Rey de la Habana nos muestran un Reynaldo adolescente que asiste aburrido a unas clases en el reformatorio y que escapa de la

\footnotetext{
${ }^{3}$ Vease: https://www.pabloperona.com/el-rey-de-la-habana
} 
realidad por medio del sueño. Su imaginación erótica se despega en esa circunstancia por medio de dibujos animados que reproducen un universo de sexo divertido, cargado de colores e ironía (Figuras 11-12), muy diferente respecto al modelo totalitario que adoptará en su relación con Magda cuando en contacto con la realidad verá su sueño derrumbarse.
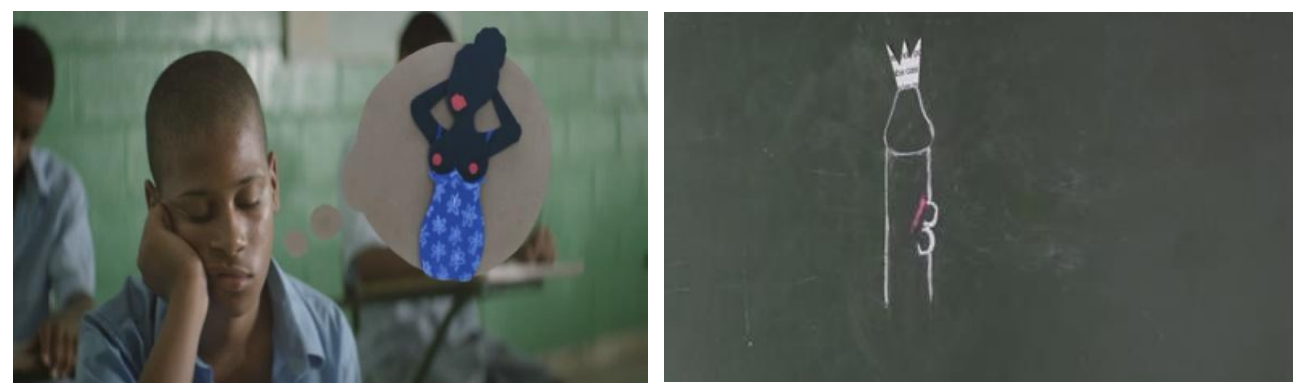

Figuras 11 y 12: Fotogramas extraídos de los créditos iniciales de la película de Agustí Villaronga que ilustran las fantasías del protagonista de niño. Fuente: DVD Filmax Home Video.

El elemento imaginativo y voyerista se conforman como el motor de la acción dentro de la película. La escena que precede a la acción que llevará al cambio de vida del protagonista nos muestra el joven mientras se asoma desde una grieta en la pared, junto a su hermano para espiar a la vecina (Figura 13). El descubrimiento de este abuso por parte de la madre provocará la violencia y causará la muerte accidental de la mujer. La acción de mirar desde una ventana, operada por el protagonista en el trascurso de la película, casi siempre anuncia un hecho trágico que se va a cumplir dentro de poco, como si esta violación de la privacidad, este acercamiento a lo prohibido y a la verdad a la vez, provoque un cambio en la narración.
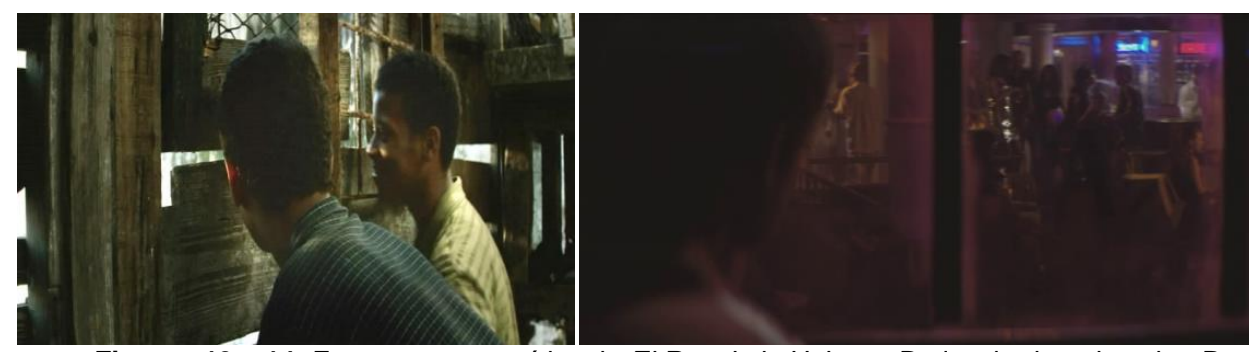

Figuras 13 y 14: Fotogramas extraídos de El Rey de la Habana. De izquierda a derecha: Rey espía a Magda con su hermano desde el patio de su casa, y en la otra, Rey vigila a Sandra desde la ventana de un club nocturno. Fuente: DVD Filmax Home Video.

En la escena en que Rey acompaña a su amiga Sandra a un local donde se va a encontrar con algunos clientes extranjeros se repite el mismo mecanismo: rechazado a la entrada por un guarda de seguridad, el chico mira por la ventana en el retro del salón de baile para poder observar lo que está pasando ahí adentro: Sandra está hablando 
con su novio italiano, el cual le entrega una gran cantidad de dinero enrollado (Figura 14). La chica sale en búsqueda de Rey y le entrega el dinero para que compre droga. Es el comienzo de un juego arriesgado que llevará a la encarcelación de Sandra y que devuelve al joven al ámbito de la ilegalidad.

Villaronga nos propone al protagonista como un ser activo, el que mira y actúa en consecuencia, mientras que a Sandra como sujeto pasivo que es objeto de la mirada de los demás, casi sin darse cuenta. La única vez que la chica parece observar la realidad que la rodea es frente al espejo mientras está usando maquillaje, o cuando cuida el cuerpo de Rey. Su mirada es la de quien sueña tener una vida mejor. Pero su sueño se ve obligado a detenerse bruscamente cuando viene condenada a la ceguera por un delincuente que la priva de los ojos para vender la retina. Rey la volverá a encontrar después de mucho tiempo en un hospital, pero ella, con gafas oscuras y muchos recuerdos traumáticos, no podrá reconocerlo sino por la voz (Figura 15). Por primera vez el cuerpo transgénero no es un cuerpo erotizado, un cuerpo vislumbrado por cortinas de encaje o que se lanza a poses o bailes sexys para deleitar a su marido o acercar posibles clientes (Figura 16). Ya no es tampoco un cuerpo que trabaja y lucha, sino se ha convertido en un cuerpo totalmente cerrado, cubierto, inaccesible porque dolido y martirizado, a diferencia del cuerpo de Magda, que sigue objetivado y sexualizado incluso en la muerte y la tragedia.
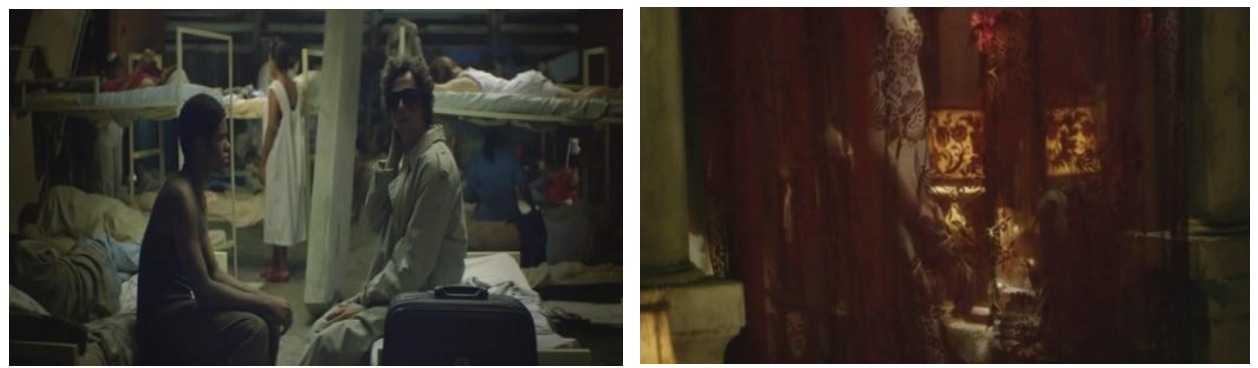

Figuras 15 y 16: Fotogramas extraídos de El Rey de la Habana. De izquierda a derecha: Rey encuentra en un hospital a Sandra privada de sus ojos por un delincuente. Al lado, escena de seducción en el piso de Sandra. Fuente: DVD Filmax Home Video.

\section{De los chavales del arroyo de Pasolini al Pixote de Babenco: entre sexualidades} periféricas y periferias erotizadas

En las primeras obras cinematográficas de Pier Paolo Pasolini así como en la famosa película de Hector Babenco, Pixote, a Lei do Mais Fraco, podemos encontrar algunos elementos comunes al Rey de la Habana de Gutiérrez y Villaronga en relación con la construcción de unas masculinidades adolescentes periféricas, a pesar de las 
diferencias temporales y espaciales entre las realidades descritas. Los aspectos en común pueden ser sintetizados en los siguientes puntos:

$>\quad$ Contexto periférico de una megalópolis (La Habana, Roma, Sao Paulo)

$>\quad$ Perfil marginal/criminal de los personajes

$>\quad$ Edad de los personajes: adolescencia o post adolescencia

$>\quad$ Relación tóxica con las mujeres/proxenetismo

$>$ Carga erótica exagerada/ hipermasculinidad

$>\quad$ Mirada queer/deseante del director

$>$ Experiencia de formación o estancia en instituciones: cárceles, hospitales...

$>\quad$ Final violento

Pier Paolo Pasolini dedicó sus primeras novelas: Ragazzi di vita (1955) y Una vita violenta (1959) a los muchachos que vivían en los suburbios de una Roma en equilibrio entre la posguerra y el boom económico. Estos jóvenes, de origen muy humilde, se dedicaban a todo tipo de actividades ilícitas e ilegales para sobrevivir en una sociedad que los había dejado totalmente de lado. La figura del "delincuente de poca monta" pasará de la página a la película unos años después cuando el intelectual italiano decidió dedicarse al cine. Accattone (1961) y Mamma Roma (1962) tratan los mismos temas en contextos parecidos a los de las obras literarias que los precedieron. A principio de los sesenta se estrenó también una película dirigida por Paolo Heusch y Brunello Rondi, basada en la segunda novela de Pasolini: Una vita violenta (1962). El protagonista de la historia, Tommaso, así como el de Accattone del año anterior, está interpretado por Franco Citti, actor fetiche del director boloñés, que venía del mismo entorno que los personajes que representaba en la pantalla.

Aún estamos lejos de la sexualidad explícita de la Trilogía de la vida (19711974) o de Saló o los 120 días de Sodoma (1975) y de la explícita exhibición de cuerpos desnudos. Limitado por un contexto muy conservador y religioso y recién salido de un juicio por obscenidades debido a la publicación de su primera novela, Pasolini parece querer ocultar en la medida de lo posible el componente homosexual de sus primeras obras fílmicas. En ellas, los personajes masculinos y femeninos están encadenados en un binarismo de género que los lleva a responder perfectamente al rol que la sociedad de la época había planteado para ellos.

Juan Vicente Aliaga, en su artículo “Los hombres de Pasolini”, retoma el término mascarada de la psicoanalista británica Joan Riviere, para referirse a la performatividad 
de género que alimenta los estereotipos sexuales masculino y femenino en las sociedades contemporáneas con el objetivo de confirmar o sobrevivir a determinadas dinámicas de poder.

De acuerdo con el crítico español podemos afirmar que: el mundo de Pasolini respetaba en aquel entonces el orden establecido en cuanto a los valores de género imperantes (ALIAGA, p. 165). Si nos detenemos particularmente en los personajes de Accattone y Tommaso, ambos frutos de la pluma de Pasolini pero llevados a la pantalla, en el segundo caso, por otros directores, encontraremos confirmación a tal enunciado; Accattone y Tommaso podrían fácilmente inspirarse en la misma tipología de persona, encarnada por Franco Citti. Lo que diferencia las dos mise-en-scène es principalmente la mirada queer con la que se nos muestran: muy participativa en Pasolini y más didascálica en Heusch y Rondi, que mantienen cierto desapego casi objetivo del tema que tratan.

La virilidad de Tommaso es "coherente", inexpugnable, libresca, es decir: responde a la perfección a un guion que no la desvía de la más común homosocialidad (figuras 17-18) que incluye momentos de intimidad platónica, de confianza intimista o confrontación de la propia virilidad que se refleja en la construcción/exaltación de un cuerpo hábil para el deporte o las peleas. La hombría de Accattone, en cambio, no está totalmente libre de grietas, "porosa" la definiría Aliaga, y no escapa al proceso de continuo cuestionamiento que sugiere la mirada "deseante" y queer del director que lo propone con un llamativo sombrero de flores mientras se mira al espejo (figura 19) 0 enfrascado en una pelea cuerpo a cuerpo con su excuñado que, por el encuadre desde un plano sujetivo, parecería casi un abrazo erótico entre los dos hombres (figura 20).
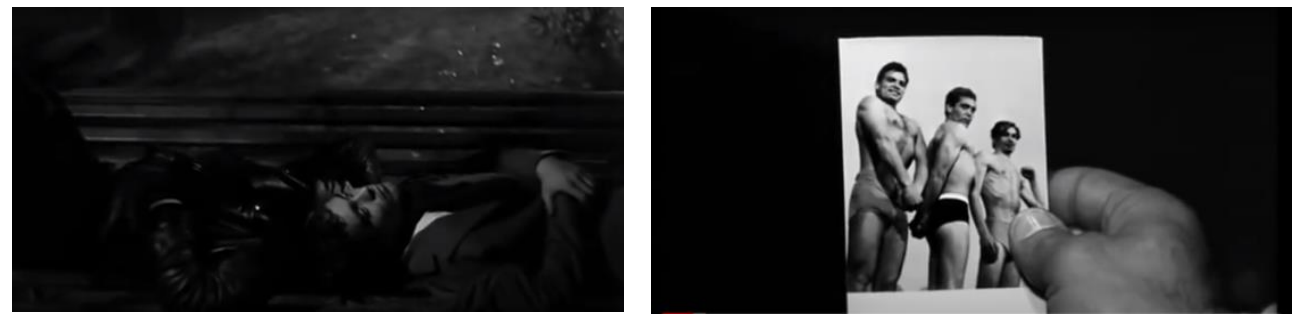

Figuras 17 y 18: Fotogramas extraídos de la película Una vita violenta, basada en la novela de Pier Paolo Pasolini y dirigida en 1962 por Paolo Heusch y Brunello Rondi. Son escenas de afecto y homoerotismo entre Tommaso, el protagonista, y los otros miembros de su pandilla.

Fuente: DVD Minerva Classics. 

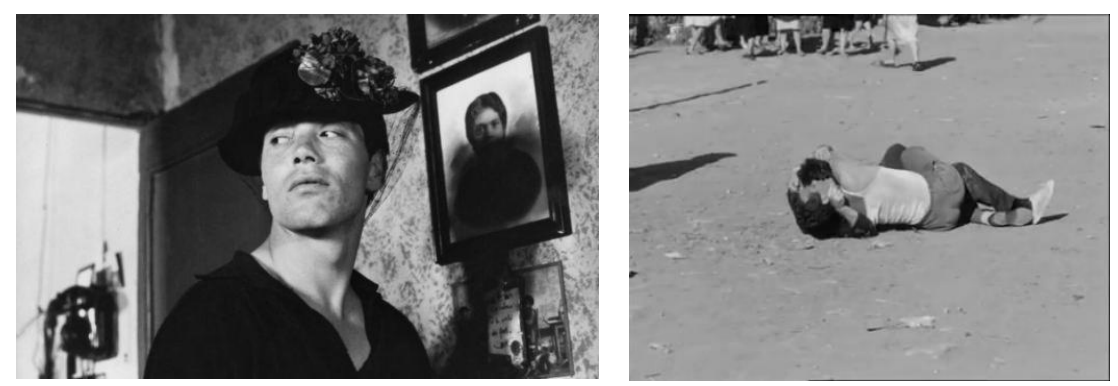

Figuras 19 y 20: Fotogramas extraídos de la película de Pier Paolo Pasolini, Accattone

(1961). El protagonista, interpretado por Franco Citti, resulta sometido a la mirada queerizante del director. Fuente: DVD Medusa home video.

Veinte años después, a principios de los ochenta, Hector Babenco llevará a la pantalla grande la historia de otros "muchachos de vida violenta" en la película Pixote, a Lei do Mais Fraco (1981) inspirada en el libro de José Louzeiro: Pixote. Infancia dos Mortos (1977). La película, influenciada por el neorrealismo italiano, se rodó entre Río de Janeiro y Sao Paulo con actores no profesionales, como se solía hacer en el género cinematográfico de referencia.

Para los propósitos de esta investigación nos centraremos en el análisis de algunos personajes, en particular de la película del director argentino/brasileño, similares por edad, trayectoria y construcción de su propia identidad de género a los del primer Pasolini y sobre todo a las dinámicas hombre/mujer presentes en El Rey de La Habana. Me refiero a Lilica y a sus parejas: Fumaça, Dito y al adulto Cristal.

Lilica es una muchacha transgender de 17 años que se encuentra encerrada en un centro de detención masculino. En la cárcel es objeto de deseo y de violencia por parte de los presos y del personal penitenciario (figura 21). En el transcurso de la película, la joven mantiene relaciones con tres personajes que proponen un modelo de masculinidad tóxica, muy similar a la de Rey, que incluye el uso de la violencia y una actitud machista caracterizada por varios intentos de prevaricación hacia ella y los demás sujetos con los que se relacionan. Si Lilica se propone encarnar al personaje de la "femme fatale" (figura 22), los sujetos masculinos a los que se acompaña intentan encajar en el papel de gangster experimentado y sin escrúpulos, imitando comportamientos e interiorizando estereotipos de masculinidad tóxica que los llevarán a ser víctimas de un entorno corrupto que acabará con sus jóvenes existencias. (figura 23) 


\section{rebeca}
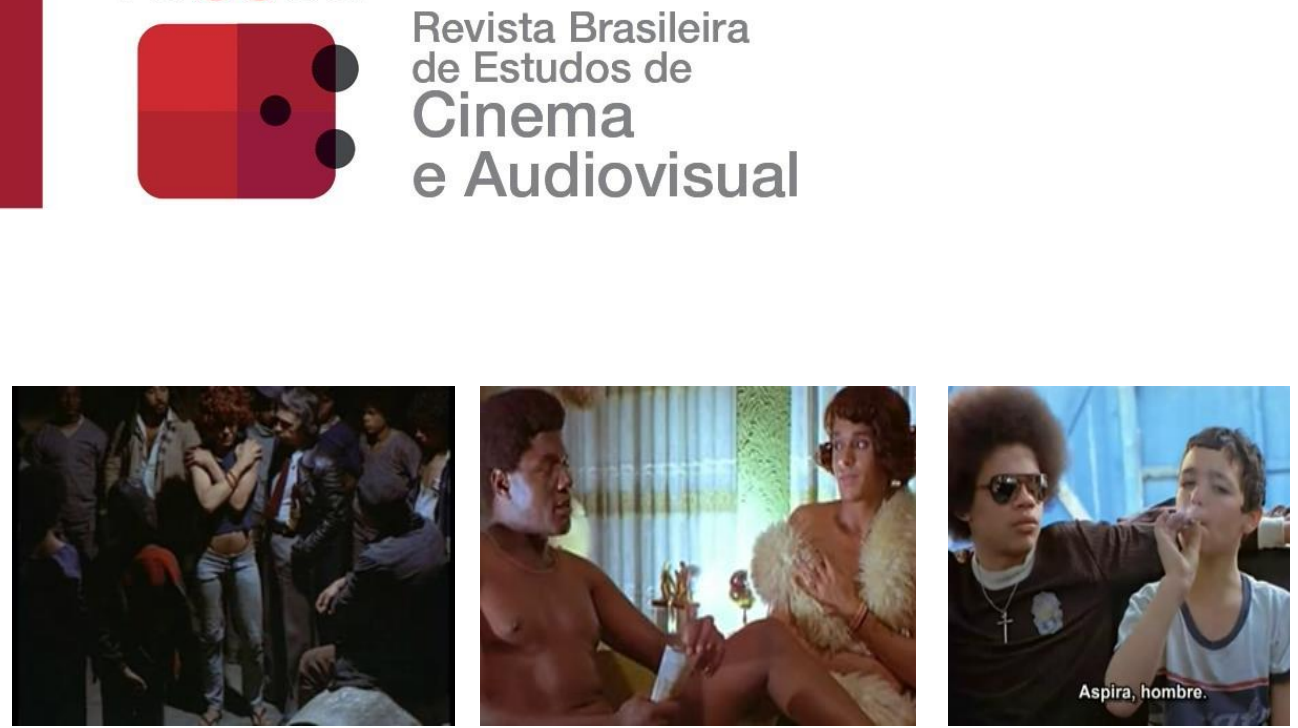

Figuras 21, 22 y 23: Fotogramas extraídos de la película Pixote, a Lei do Mais Fraco, de Héctor

Babenco (1980). Tres momentos de la historia de Lilica que evidencian la construcción de una masculinidad tóxica por parte de los personajes que la rodean. Fuente: DVD Pride.

A diferencia de los niños inocentes del Nuevo Cine Español utilizados como "figuras propicias para construir alegorías políticas" de la propia España en el paso entre un "pasado represivo" y "la esperanza de un futuro emergente" (PÉREZ, 2017: p. 106), los muchachos de Babenco y de El Rey de La Habana tuvieron que renunciar a su inocencia para enfrentar un futuro que le venía negado. Lo que los une, todavía, es la subversión de la lógica de la temporalidad reproductiva (HALBERSTAM, 2005) que suele caracterizar al camino heterosexual, fundamental para poder insertar los cuerpos en el sistema de producción capitalista. Esta naturalización por parte de la sociedad de la temporalidad reproductiva, denominada por Lee Edelman "heterofuturity" (2004), tiende a suponer que los menores sean necesariamente heterosexuales. (PÉREZ, 2017: p. 108)

Los personajes de Babenco como los de Gutiérrez se portan como adultos y se sienten adultos a pesar de que no los sean. Los adultos de verdad que deberían tutelarlos y cuidarlos no los respetan en lo más mínimo como sujetos sociales de derecho sino los ven como propiedad, como pequeños adultos, o como seres malvados por nacimiento.

Antonio Caballero Gálvez describe esa pérdida de la inocencia en su ensayo sobre la representación de la homosexualidad en Pa negre de Agustí Villaronga donde retoma los conceptos de ghosty gay child y de growing sideways elaborados por Kathryn Bond Stockton (2009) para indicar una maduración sexual y sentimental que se manifiesta de forma transversal, irregular si comparada con la heterosexual definida vertical por Hogan (2016). Un camino a la edad adulta que es descrito por los directores aquí mencionados como no exento de obstáculos, negociaciones y encubrimientos, con pocas luces y muchas sombras y que a menudo conduce a situaciones relacionadas con el crimen y la violencia

La primera noche de la estancia de Pixote en la cárcel de menores estará marcada por la violencia grupal contra un adolescente que poco después morirá. Algo 
parecido a lo que describe El Rey de La Habana en relación a la permanencia del protagonista en el centro para menores. No le va mejor a las chicas trans: Lilica admite ver para sí un futuro sin esperanzas y prefiere la soledad a sucumbir al machismo del chico que ama. La Sandra de la película de Villaronga terminará sus días ciega en un hospital, víctima de un delincuente que la privó de los ojos para venderlos en el mercado de órganos. Los muchachos de Pasolini en sus primeras obras literarias o en la novela autobiográfica Amado mío/Actos impuros (1982) ejercen la prostitución masculina o viven sus experiencias homosexuales escondidos en cuevas o matorrales como el Pitorliua, ser mitad hombre mitad pájaro, de Pan Negre de Villaronga que, sin embargo, termina castrado y en exilio. Todos estos personajes parecen haber sido condenados por parte de la sociedad a la dimensión de lo monstruoso, del abyecto o de lo indeseable.

Todos aquellos que por razones étnicas, económicas, sociales, de orientación sexual o de identidad de género no se integran a los mecanismos de producción o a los modelos hegemónicos, automáticamente son percibidos por las sociedad burguesa como sobra, como un desperdicio que debe ser aislado, aniquilado o impulsado a que se auto elimine. La metáfora de la basura o del barro, ya analizada en relación a la obra de Villaronga, está presente también en las obras de Pasolini y Babenco, para denunciar este proceso colectivo de discriminación. La encontramos en relación al personaje de uno de los chicos del reformatorio, cuyo cadáver es encontrado días después de su desaparición en la basura (figura 23) mientras que en el trabajo de Pasolini, el basurero es donde las dos mujeres amadas por Accattone, tanto Stella como su ex esposa, trabajan reciclando botellas de vidrio. (figura 24)
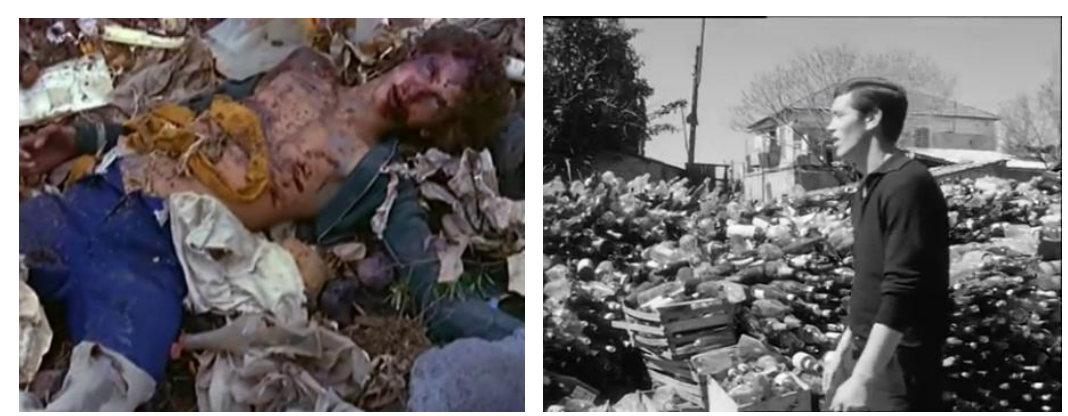

Figuras 23 y 24: Fotogramas extraídos de Pixote a Lei do Mais Fraco y de Una Vita Violenta. Ambas imágenes representan la metáfora persistente que los directores de las dos películas, así como fue planteado por Villaronga en relación a Rey, establecen entre sus personajes y la basura, como si quisieran afirmar que el destino de estas personas fuera ineluctable: ser despreciadas, explotadas y finalmente desechadas. Fuente: DVD Home Video.

Rey, Pixote y Accattone están totalmente alejados del poder cuyo propósito, nos advierte Elias Canetti (1960), es el de engullir, incorporar y explotar a los adversarios, 
reduciéndolos a sus propios excrementos para ser secretamente expulsados. Quien, a pesar de todo, logra mantenerse a flote y no sucumbir es un sobreviviente que, por haber escapado de la muerte, puede disfrutar del momento de alivio que le otorga ese particular estado de elección. El superviviente es, en última instancia, el que ha superado la muerte y cuya corporeidad sigue esencialmente intacta. Como afirma el escritor búlgaro: "el superviviente se enfrenta a una o más muertes" y quien sobrevive a su enemigo varias veces es un héroe, muchas veces contagiado por la peligrosa convicción de ser invulnerable, la misma que junto a los factores que hemos descrito fue fatal para los protagonistas de las historias aquí analizadas.

\section{Conclusiones}

El machismo y la masculinidad tóxica son fenómenos universales que afectan a varias sociedades en diferentes partes del mundo y en formas determinadas por cuestiones históricas, sociales y culturales y suelen manifestarse a menudo a través de una serie de prácticas dañinas que se pueden definir "micromachismos". Luis Bonino refiere al respeto que:

los mM son prácticas de dominación y violencia masculina en la vida cotidiana, del orden de lo "micro", al decir de Foucault, de lo capilar, lo casi imperceptible, lo que está en los límites de la evidencia. El prefijo "micro" del neologismo con el que nombro a estas prácticas alude a esto. [...] Los mM son micro abusos y micro violencias que procuran que el varón mantenga su propia posición de género creando una red que sutilmente atrapa a la mujer, atentando contra su autonomía personal si ella no las descubre (a veces pueden pasar años sin que lo haga), y sabe contra maniobrar eficazmente. Están la base y son el caldo de cultivo de las demás formas de la violencia de género (maltrato psicológico, emocional, físico, sexual y económico) y son las "armas" masculinas más utilizadas con las que se intenta imponer sin consensuar el propio punto de vista o razón. (BONINO, 2008: p. 3-4)

El trabajo de Bonino pone en evidencia el elemento temporal de la repetición y de la intensidad que pueden caracterizar estos comportamientos para que se pueda perpetuar un "poder" hacia la otra persona. Se trata de operaciones deshonestas que a veces tardan en ser descubiertas excepto cuando llegan a un nivel de violencia muy alto. Es por esta razón que el estudioso subraya la necesidad de visibilización del problema y el cuestionamiento de lo que es la masculinidad. 
Por ser los hombres heterosexuales los principales detentores de poder, el modelo a seguir de un mundo que gira alrededor de ellos, resulta a veces difícil percibir las voces de los "dominados entre los dominantes" (BLANCO LÓPEZ, 2019: p. 201) que pueden convertirse ellos mismos en víctimas del sistema o en verdugos hacia las sujetos sociales más débiles. Juan Blanco López, Guadalupe Cordero Martín y José María Valcuende del Río (2019: p. 199). En su ensayo sobre masculinidad, invisibilidad y vulnerabilidad se citan una serie de estudios que parecen confirmarnos cuanto acabamos de expresar:

Los hombres, en tanto que sujetos generizados, se encuentran paradójicamente, invisibilizados por un "modelo de intervención" que les excluye, precisamente por asociar al individuo, entendido en clave masculina, con el ciudadano de pleno derecho (MOSSE, 2000). En la modernidad lo masculino subsume (VALCUENDE, 2003). Ahora bien, si tal y como nos proponen Sabuco y Valcuende, la masculinidad incluye a todas las categorías desde la exclusión, también la masculinidad puede convertirse en causa de exclusión, de los hombres que interiorizan el modelo dominante, que no solo establece los cánones a seguir por los varones que aspiran al éxito social, sino que además se convierte en el modelo a partir del que se jerarquizan otras corporalidades sexuadas y racializadas (VALCUENDE, VASQUEZ, 2016).

Desde el período de la diferenciación de género en la infancia, los niños varones siguen siendo educados en muchos contextos con todos los privilegios y con la convicción y la carga de expectativas para que sean exitosos una vez adultos. El fracaso no está contemplado, la inactividad tampoco. Así que como nos confirma el trabajo de Synai (2006): "la normativización de la masculinidad tóxica impide a los hombres excluidos de visibilizar las causas" debido a que no entienden cómo a pesar de haber adherido al modelo hegemónico de "hombría" se encuentren en una situación de marginalidad y no de éxito". (BLANCO LÓPEZ, 2019: p. 201)

La incapacidad de aceptar un rechazo, el peso del fracaso (social y sentimental), junto a un alto nivel de riesgo relacionado con un modelo tóxico de masculinidad llevado al extremo, son propiamente las causas de muerte del protagonista de la novela de Gutiérrez y de su trasposición cinematográfica. El muchacho se percibe y quiere ser reconocido como el "Rey de la Habana" pero se equivoca gravemente en la forma de conseguir su sueño. 
La historia de Reynaldo permite analizar algunas dinámicas en relación al machismo como fenómeno universal. De acuerdo con González Pagés (2019: p. 71) nos cuestionamos sobre la relación entre este fenómeno y las identidades latinoamericanas rechazando una visión esencialista que intente promover la idea de "Latinoamérica como cuna del machismo" sin por esto querer pasar por alto a las características locales. El fenómeno del machismo es transversal y dinámico: va más allá de la clase social y económica del abusador o de la víctima, más allá de la pertenencia étnica o geográfica. El estudioso cubano sugiere que hay que entender la masculinidad como una "manifestación histórica creada desde la sociedad y la cultura de cada región y no como una forma estática e inamovible" y que hay que intentar verla "desde varias dimensiones que ubiquen raza, etnia o clase en un mismo eje cognoscitivo y no de forma fragmentaria para poder investigar la identidad y sus efectos múltiples". El presente trabajo quiere colocarse en ese camino con el fin de alimentar el diálogo entre los géneros y dentro de las mismas masculinidades para poder construir o apoyar nuevas formas de ser hombre que respeten los valores humanos positivos, más allá de los roles binarios.

\section{Referencias}

ALIAGA, Juan Vicente. "Los hombres de Pasolini. Virilidad y juventud en la obra de un homosexual italiano". Dossiers Feministes (6), 2002, 161-169.

BABENCO, Hector. Pixote. Embrafilme, 1981.

BADINTER, Elisabeth. $X Y$, la identidad masculina. Barcelona: Grupo editorial Norma, 1993.

BLANCO LÓPEZ, Juan; CORDERO MARTÍN Guadalupe y VALCUENDE DEL RíO, José María. "Ejercer de hombres: masculinidad, invisibilidad y vulnerabilidad". En MARTÍNEZ GUIRAO, Javier Eloy; Téllez Infantes, Anastasia y Sanfélix Albelda, Joan (Ed.). Deconstruyendo la masculinidad. Cultura, género e identidad. Valencia: Tirant Humanidades, 2019. 183-193.

BONINO, Luis. "Micromachismos. El poder masculino en la pareja moderna". En LOZOYA, José y BEDOYA, José Ángel (Ed.). Voces de hombres por la igualdad. Madrid: Chema Espasa ediciones digitales, 2008.

BOURDIEU, Pierre. La domination masculine. Paris: Éditions du Seuil, 1998.

BRANNON, Robert; DAVID, Deborah S. The forty-nine percent majority. Boston: Addison-Wesley Publishing Company, 1976.

CABALLERO GÁLVEZ, Antonio A. "Perversión y monstruosidad: la representación de la homosexualidad en Pa negre de Agustí Villaronga". Interalia: a journal of queer studies (12), 2017, 191-199.

CANETTI, Elias. Massa e potere. Milano: Adelphi editore, 1972. (Obra original publicada en 1960). 
CONNELL, Raewyn R. Masculinities. Berkeley: University of California, 1995.

CONNELL, Raewyn R. "La organización social de la masculinidad". En VALDÉS, Teresa y OLAVARRIA José (Eds.). Masculinidades. Poder y crisis. ISIS-FLACSO: Ediciones de mujeres, 1997, 31-48.

EDELMAN, Lee. No Future: Queer Theory and the Death Drive. Durham: Duke UP, 2004.

FACHEL LEAL, Ondin. "Suicidio y honor en la cultura gaucha". En Valdés, Teresa y Olavarría, José (Ed.). Masculinidades Poder y Crisis. Isis Internacional/FLACSO, 1997, pp. 113-124.

FULLER, Norma. Identidades masculinas. Lima: PUCP, 1997.

GOFFMAN, Erving. Ritual de la interacción. Buenos Aires: Editorial Tiempo Contemporáneo, 1970.

GÓMEZ RIVERA, Jimmy J. "Percepciones, discursos y prácticas de las masculinidades desde el entorno del fútbol". En ARROYO, Roxana y JIMÉNEZ Rodrigo (Ed.). Masculinidades en la cultura del fútbol, 1998.

GONZÁLEZ PAGÉS, Julio César. Macho, varón, masculino. Estudios de masculinidad. La Habana: Editorial de la Mujer, 2010.

GONZÁLEZ PAGÉS, Julio César. "Estudios de masculinidades en América Latina". En MARTÍNEZ GUIRAO, Javier Eloy; TÉLLEZ INFANTES, Anastasia y SANFÉLIX Albelda, Joan. Deconstruyendo la masculinidad. Cultura, género e identidad. Valencia: Tirant Humanidades, 2019.

GUTIÉRREZ, Pedro Juan. (1998). Trilogía sucia de La Habana. Barcelona: Editorial Anagrama, 1998.

GUTIÉRREZ, Pedro Juan. El Rey de La Habana. Barcelona: Editorial Anagrama, 2001.

HALBERSTAM, Judith. In a Queer Time and Place. New York: New York UP, 2005.

HEUSCH, Paolo; RONDI, Brunello. Una vita violenta. Zebra Films, 1962.

HOGAN, Erin K. "Queering Post-War Childhood: Pa negre (Agustí Villaronga, Spain 2010)". HispanicResearch Journal (17.1), 2016, pp. 1 -18.

KIMMEL, Michael. "El desarrollo (de género) del subdesarrollo (dé genero): la producción simultánea de masculinidades hegemónicas y dependientes en Europa y Estados Unidos". En VALDÉS, Teresa y OLAVARRÍA, José. Masculinidades y equidad de género en América Latina, Chile: Flacso-Chile editores, 1998.

LÓPEZ, Maria Ángela. La violencia juvenil. Su cultivo en la sociogénesis del varón. Razón y Fe. Revista Hispanoamericana de Cultura, n. 1160, 1995.

LOUZEIRO, José. Pixote. Infancia dos mortos. São Paulo: Global Editora, 1987.

MAILER, Norman. Prisionero del sexo. Buenos Aires: Emecé editores, 1985. 
MARTÍNEZ GUIRAO, Javier Eloy. Cuerpos en riesgo. Implicaciones y consecuencias de la masculinidad en las corporeidades. En Deconstruyendo la masculinidad. Cultura, género e identidad. Valencia: Tirant Humanidades, 2019.

MOSSE, George L. La imagen del hombre. La creación de la masculinidad moderna, Madrid: Talasa Editores, 2000.

PALMA, Norman. Digresiones sobre el goce y el sufrimiento en el horizonte ecológico del macho. Simbólica de la feminidad. Colección 500 años, 1990.

PASOLINI, Pier Paolo. Accattone. Arco Film, 1961.

PASOLINI, Pier Paolo. Amado mio. Milano: Garzanti Editore, 1982.

PASOLINI, Pier Paolo. Mamma Roma. Arco Film, 1962.

PASOLINI, Pier Paolo. (1955). Ragazzi di Vita. Milano: Garzanti Editore.

PASOLINI, Pier Paolo. (1959). Una vita violenta. Milano: Garzanti Editore.

PÉREZ, Jorge. The Queer Child in the Nuevo Cine Español. Interalia: a journal of queer studies (12), 2017, pp. 106-119.

PESCADOR, Eric. Masculinidades y adolescencia. En Lomas, Carlos (Ed.). Los chicos también Iloran: identidades masculinas, igualdad entre los sexos y coeducación. Barcelona: Paidós Ediciones, 2004.

RIVIERE, Joan. Womanliness as a masquerade. International Journal of Psychoanalysis, Vol. 10, 1929, pp. 303-13.

RUIZ BRAVO, Patricia. Sub-versiones masculinas. Lima: Editorial Flora Tristán, 2001.

SINAY, Sergio. La masculinidad tóxica: un paradigma que enferma a la sociedad y amenaza a las personas. Argentina: Ediciones B, 2006.

STOCKTON, Kathryn Bond. The Queer Child, or Growing Sideways in the Twentieth Century. Durham: Duke UP, 2009.

VALCUENDE, José María, Blanco, Juan. La construcción cultural de las masculinidades. Madrid: Editorial Talasa, 2003.

VALCUENDE, José María, Vásquez. Piedad. Orden corporal y representaciones raciales, de clase y género en la ciudad de Cuenca (Ecuador). Chungará (Arica), vol. 48, No2, 2006.

VILLARONGA, Agusti. El Rey de La Habana. MagPictures, 2015.

VILLARONGA, Agusti. Pa Negre. Massa d'Or PC, 2010. 